\title{
FORAGING TACTICS IN MOLLUSCA: A REVIEW OF THE FEEDING BEHAVIOR OF THEIR MOST OBSCURE CLASSES (APLACOPHORA, POLYPLACOPHORA, MONOPLACOPHORA, SCAPHOPODAAND CEPHALOPODA)
}

\author{
Vanessa Fontoura-da-Silva, ${ }^{1,2}{ }^{*}$, Renato Junqueira de Souza Dantas ${ }^{1}$ and Carlos Henrique Soares Caetano \\ ${ }^{1}$ Universidade Federal do Estado do Rio de Janeiro, Instituto de Biociências, Departamento de Zoologia, Laboratório de Zoologia de \\ Invertebrados Marinhos, Av. Pasteur, 458, 309, Urca, Rio de Janeiro, RJ, Brasil, 22290-240. \\ ${ }^{2}$ Programa de Pós Graduação em Ciência Biológicas (Biodiversidade Neotropical), Universidade Federal do Estado do Rio de Janeiro \\ E-mails: vanessa_fontoura@globo.com,renato.biomar@gmail.com, chcaetano@zipmail.com.br
}

\begin{abstract}
Mollusca is regarded as the second most diverse phylum of invertebrate animals. It presents a wide range of geographic distribution patterns, feeding habits and life standards. Despite the impressive fossil record, its evolutionary history is still uncertain. Ancestors adopted a simple way of acquiring food, being called deposit-feeders. Amongst its current representatives, Gastropoda and Bivalvia are two most diversely distributed and scientifically well-known classes. The other classes are restricted to the marine environment and show other limitations that hamper possible researches and make them less frequent. The upcoming article aims at examining the feeding habits of the most obscure classes of Mollusca (Aplacophora, Polyplacophora, Monoplacophora, Scaphoda and Cephalopoda), based on an extense literary research in books, journals of malacology and digital data bases. The review will also discuss the gaps concerning the study of these classes and the perspectives for future analysis.
\end{abstract}

Key words: diet, feeding habits, mollusks

\section{RESUMO}

TÁTICAS DE FORRAGEAMENTO EM MOLLUSCA: UMA REVISÃO SOBRE O COMPORTAMENTO ALIMENTAR DAS SUAS CLASSES MAIS OBSCURAS (APLACOPHORA, MONOPLACOPHORA, POLYPLACOPHORA, SCAPHOPODA E CEPHALOPODA).

O filo Mollusca é o segundo mais diverso e, portanto, apresenta os mais variados hábitos de vida, padrões de distribuição geográfica, comportamentos alimentares, dentre outros aspectos. Apesar de seu rico registro fóssil, a história evolutiva do grupo ainda é incerta. Os táxons tidos como ancestrais do filo alimentavam-se de forma simples, sendo considerados depositívoros. Dentre os representantes atuais, as classes Gastropoda e Bivalvia são as mais diversas e amplamente distribuídas, sendo as mais conhecidas cientificamente. As demais classes, por outro lado, estão restritas ao ambiente marinho e exibem outras limitações que dificultam o seu estudo e o tornam menos freqüente. Aqui será apresentada uma síntese dos hábitos alimentares das classes mais obscuras do filo Mollusca (Aplacophora, Polyplacophora, Monoplacophora, Scaphoda e Cephalopoda) com base em uma extensa busca em livros, principais periódicos de Malacologia e bases de dados digitais. Além disso, realiza-se uma discussão acerca das lacunas de conhecimento e das perspectivas para estudos futuros.

Palavras-chave: dieta, hábitos alimentares, moluscos

\section{INTRODUCTION}

Amongst all the activities performed by an animal, perhaps the most important is finding and consuming food. Besides being an individual necessity, feeding is crucial for various levels of ecosystem processes (O’Brien et al. 1990). Different phenotypes have different abilities to acquire food, which are distributed in patches around the environment (Mac Arthur and Pianka 1966). Aiming to predict the foraging behavior patterns of the animals which actively look for feeding resources, Mac Arthur and Pianka (1966) developed the Optimal Foraging Theory. The study has received several contributions over the years regarding the consumers preferences, habitat selection and territories dimensions. These studies also investigated if they are going to hunt in groups, the ideal size of such groups, the foraging period choice and, at last, the level of specialization and generalism (Belosvsky 1978, Pyke and Pullian 1977, Schoener 1971, 1973, 1983, 1987, Stephens and Krebs 1986). The Optimal Foraging Theory or behavioral ecology can be defined as the maximum return of energy obtained under foraging and habitat conditions (Townsend et al. 2010, Odum and Barrett 2011). The behavior pattern of an individual subjected to natural selection is the sum of the decisions that determine its diet and its food chain structure (Petchey et al. 2008). 
Different species detain different foraging strategies to minimize energy expenditure and maximize their gains, selecting the potential feeding items and the areas or spots to be hunted (Odum and Barrett 2011).

True predators and grazers typically forage. Amongst the mobile prey predators, the most renowned foraging strategies are: the Sit-and-wait Hunter, in which they set up ambushes to catch their preys (therefore, the method is based on the evasive behavior of the latter); and the Active Hunters, in which the predators move around their own habitat looking for preys - their contact is, consequently, determined by the behavior of the predators (Greene 1986, Townsend et al. 2010). The sit-and-wait strategy is less studied, but recent researches have shown that it is more changeable than what had been predicted in the past, depending on the internal state of the individuals and their interactions with the environment (Hugie 2003, Scharf et al. 2011). Lima and Dill (1990) indicate, in their review, that the protection against predation may deeply influence the choices made by a determined species during the foraging process.

Feeding is regarded as one of the main pillars of the taxonomic diversity. By influencing population dynamics and the organization of communities, trophic interactions, alongside with competition, it molds ecological niches, which, in an evolutionary time scale, lead to radiation (Hughes, 2009). Given this thought, the mollusks are the second most diverse phylum in the world, with 100.000 Recent species described, therefore, they present the most diverse life styles, geographic distribution patterns, feeding habits, amongst other aspects (Haszprunar 2001, Caetano et al. 2007). Within the classes of the phylum Mollusca, Gastropoda and Bivalvia are the most analyzed in the scientific field. Since they are the two most diversified and welldistributed groups, they become more accessible to studies and researches. Gastropods can be found in all environments (marine, terrestrial and freshwater) and bivalves can be spotted everywhere, but in terrestrial areas (Caetano et al. 2007). The remaining classes, on the other hand, are limited to marine environment, with most of the representatives of Aplacophora and Monoplacophora being found below depths of 200m (Martins 2008, Wilson et al. 2009).

The present article proposes a knowledge synthesis on the foraging strategies of the less examined classes of the phylum Mollusca (Aplacophora, Polyplacophora, Monoplacophora,
Scaphopoda and Cephalopoda) showing the gaps of knowledge and discussing the perspectives of future studies.

\section{MATERIAL AND METHOD}

An extensive research was held from October to November 2012 and went through books of malacology and the main journals in this same subject (American Malacological Bulletin, Malacologia, Journal of Moluscan Studies, Journal of Shellfish Research, Molluscan Research, The Nautillus, The Veliger), as well as the following bases of digital data: "Periódicos CAPES", Web of Science, Google Scholar using the keywords: "foraging" + "scaphopoda or aplacophora or monoplacophora or cephalopoda or polyplacophora", "feeding behavior" + "scaphopoda or aplacophora or monoplacophora or cephalopoda or polyplacophora", "feeding habits" + "scaphopoda or aplacophora or monoplacophora or cephalopoda or polyplacophora" and "diet" + "scaphopoda or aplacophora or monoplacophora or cephalopoda or polyplacophora". After the research effort, only published articles and final papers (monographs and thesis) were considered.

\section{HISTORY OF RESEARCHES ABOUT FORAGING IN MOLLUSCA}

The phylum Mollusca comprises several feeding habits, having the radula as the fundamental organ of food capture and disposing of a wide range of foraging tactics (Caetano et al. 2007). In some groups, the radula is not related to food capture, but to postingestion processes. This will be detailed further.

Despite the huge diversity of the group and its rich shelly fossil record, their early evolutionary history remains uncertain. Two taxa from the Middle Cambrian, Wiwaxia corrugata and Odontogriphus omalus, have been considered as the ancient members that might have originated the mollusks, exhibiting a radula-like organ very similar to the one found in the genus Helicoradomenia, an extant solenogaster. Their radular function was probably limited to sweeping food from a surface, abrading soft tissues and excavating sediments, thus being classified as grazing depositfeeders (Scheltema et al. 2003, Smith 2012).

In this review, we found a total of 79 references related to the subject discussed here (Figure 1). The foraging tactics within the classes Monoplacophora and 
Aplacophora (Solenogastres and Caudofoveata) are less known. This can be explained by the fact that most of their species live in deep water and, consequently, are difficult to be reached (Okusu and Giribet 2003).

In the last 20 years, the study on the classes behavior has faced a considerable increase (Figure 1) due to the new filming and photography technologies that enabled researchers to have a deeper look into areas that were once unknown. Until 1952, the class Monoplacophora was regarded only as a fossil group, and then was found in the abyssal waters of the Pacific Ocean, in Costa Rica (Lemche and Wingstrand 1959). Not only until 1978 was the first species of Monoplacophora studied in laboratory and had a few of its ecological aspects analyzed. However, the animal was kept alive for 25 days and not many conclusions were taken from the experience (Lowenstam 1978, Wilson et al. 2009). Also, most species of Scaphopoda and Aplacophora have small size and live in great depths always digging in the sediment, which complicates the conduction of researches. Cephalopoda, on the other hand, are much more studied, due to development of industrial fishing and to their economic importance (Figure 1).

\section{APLACOPHORA FORAGING BEHAVIOR}

The Aplacophora are divided in two larger taxa: Solenogastres and Caudofoveata. The separation of the two groups, both discovered in Scandinavia in 1844 and 1875 (respectively), is related to the existence of a little foot inside the ventral furrow of the Solenogastres and its absence in the Caudofoveata (Glaubrecht et al. 2005).

The representatives of this class are exclusively marine, have vermiform bodies, covered with a cuticle or calcareous spicules, among other plesiomorphic aspects of the phylum Mollusca (Scheltema and Schander 2000). They are more numerous and present a greater diversity in depths of more than 200 meters (Martins 2008). Most researches on the class comprise their anatomy and phylogenetic and very little is known about their life story, behavior and physiology (Lamprell and Scheltema 2001). As well as the other mollusks,

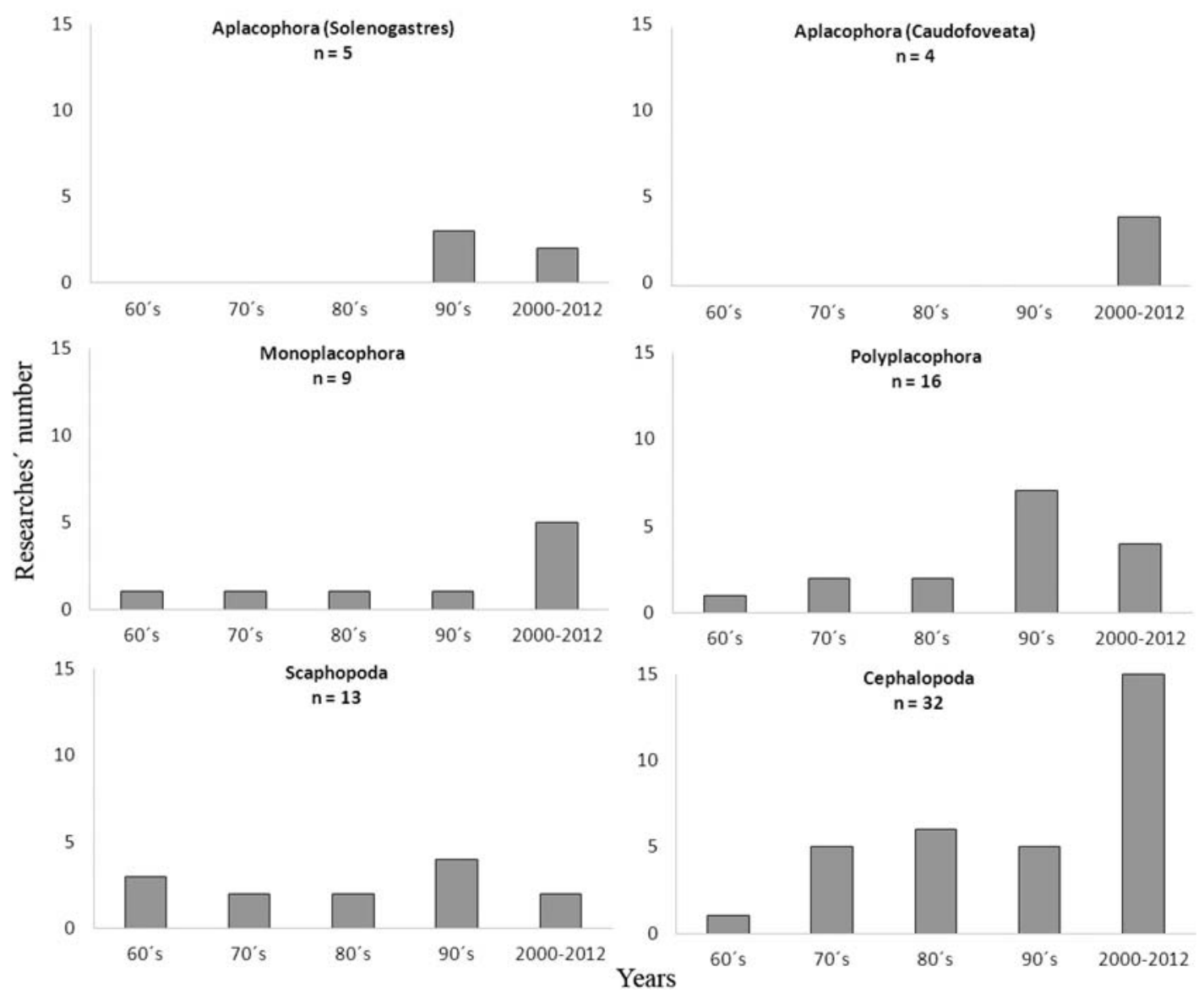

Figure 1. Studies of foraging habits of Aplacophora, Monoplacophora, Polyplacophora, Scaphopoda and Cephalopoda over the years. 
Solenogastres and Caudofoveata have a discrete buccal mass with a radula, radular sac, and paired or fused bolsters with their protractor and retractor muscles. Radulae vary morphologically and several Solenogastres have none (Beesley et al. 1998).

\section{SOLENOGASTRES}

The diet of the Solenogastres is determined through the observation of their stomach content or, in some cases, due to the fact that the species are found fixed to their preys (Scheltema 1992). The radula of Solenogastres is considered not to be used for rasping the food, because it is formed of a weak cuticle and the distal teeth are not worn (Scheltema and Jebb 1994).

As regards the foraging tactics adopted by the Solenogastres, it is known that they have, in their ventral furrow, a narrow and ciliated delta, with which they creep on soft and hard substrates or on colonies of cnidarians which serve them as food (Ponder and Lindberg 2008). The strategy is well described for the genera Epimenia, which hooks the teeth into the soft coral prey, holding the head in place, while the pharynx sucks in the polyps. It is believed that the species Epimenia australis may detect their soft coral preys through chemical sense (Scheltema and Jebb 1994).

According to other studies, the group also consumes bacteria and not only cnidarians (Scheltema et al. 2003, Morse and Norenburg 1992, Okusu and Giribet 2003).

\section{CAUDOFOVEATA}

The Caudofoveata have infaunal habits and move through hydrostatic action, feeding themselves with detritus or with selected foraminifera, burying their suboral or perioral shield, located in the upper oral region, in the mud (Glaubrecht et al. 2005, Ponder and Lindberg 2008).

The family Prochaetodermatidae is numerous and ecologically important in the macrobenthos of deep waters, which prompts the researches on the subject. The individuals of this familiy are the only ones that present, in their feeding apparatus, a pair of cuticular jaws that hold the food as two plucks while it is scraped by a little radula (Scheltema and Ivanov 2000).

\section{POLYPLACOPHORA FORAGING BEHAVIOR}

The individuals of this class, also named chitons, are one of the oldest representatives of the phylum
Mollusca, with a fossil record that extends from as early as the Upper Cambriam (Ponder and Lindberg 2008). Living on hard sediments, these slow-moving animals may appear in the bathyal zone or in the intertidal zone. Their feeding habits have also been understudied (Boyle 1977, Latyshev et al. 2004).

The chitons leave their small depressions or holes to forage usually in nights of low tide, aiming to avoid possible predators and the dissecation caused by sun exposure. In their feeding process, they usually stretch their radula and a sensorial subradular tongue-like organ (Eernisse and Reynolds 1994); since they have lateral teeth hardened by the incorporation of minerals such as iron and calcium to a organic mold, they manage to scrape hard surfaces to obtain food, generally algal cover (Shaw et al. 2002). After eating, they return to their small depressions or holes and remain there during the day, when the excretion process starts (Hulings 1991, Barbosa et al. 2008). Some chitons may also graze in low tide mornings, as long as the foraging zone is not exposed to the sun (Cretchley et al. 1997).

According to Sirenko (1998, 2000), the Polyplacophora can be divided in six different feeding habits: herbivores, detritivores, omnivores, carnivores, epizoophagous and true predators. Most chitons are generalist grazers of hard substrata, feeding mainly on microflora, algae and small encrusting animals (Eernisse and Reynolds 1994). However, there are some species that feed on detritus such as skeletons of diatoms, foraminiferans, radiolarians, spicules of calcareous sponges and even sunken wood, which was observed in some species of Lepidopleurina that inhabit regions up to 8000 meters deep (Beesley et al. 1998). Barnes (1972) studied the species Tonicella lineata feeding on coralline algae and was overwhelmed when he realized that the animal did not scrape the rock until the algae layer was completely destroyed, as it would occur with the patelid gastropods, but ingested only the layers above the meristem. The experiment underlined Putman's (1990) results, which had identified a selective foraging behavior in the species Stenoplax heathiana. Langer (1983), on the other hand, while studying the feeding habits of three chiton species in the Atlantic, realized that they scraped the epibenthic film of algal-covered substrates, being common the accidental intake of the sediment. Piercy (1987) highlighted the same behavior pattern in his researches.

When it comes to carnivorous chitons, the 
majority feed on sedentary animals, as well as, sponges, bryozoans, coelenterates and young barnacles (Beesley et al. 1998). The carnivorous chiton of the genus Placiphorella had its foraging habits observed by McLean (1962), who described the process as follows: the animal lifts the head-flap, which is a variation of the mantle margin, and keeps the oral tentacles adhered to the surface that it is found on. Any stimulus in the area prompts a quick reflex of lowering the flap, to catch the potential prey. The tentacles are then slowly raised and retracted so that the mouth can be expanded towards the prey and the ingestion happens. In some cases, the tentacles also help manipulating the prey. Another interesting observation on the genera Placiphorella is that the inferior face of the headflap exhibits strong staining, which may serve as a distraction for preys with average visual capability (Clark 1994). A similar predatory behavior was described for Loricella angasi and two species of Craspedochiton (Eernisse 2007).

\section{MONOPLACOPHORA FORAGING BEHAVIOR}

The Monoplacophora dispose of only one valve, shaped as a convex dorsal shield with its apex facing towards the upper region and length from 1.5 to 3.7 millimeters (Caetano et al. 2007). The Monoplacophora is, undoubtedly, the less studied class of the phylum Mollusca. There is a considerable gap concerning its ecological and ultrastructural aspects, immunocytochemistry and ontogenetic (including the evo-devo) (Ponder and Lindberg 2008). A deeper knowledge of the representatives of this class, which was believed to be extinct, is seen as an important key to the study of the evolution of the phylum (Schwabe 2008).

Laevipilina hyalina is the most accessible species of the group in terms of habitat, since it lives in depthless waters (174-388 meters deep). It was the first one to be photographed live and cultivated in aquarium, which made it become rather well-known (Wilson et al. 2009). In one of the few researches on the species, no feeding activity was registered; however another three studies suggest that the Monoplacophora might be generalists, feeding on detritus and foraminifera, as well as specialists in protozoans of the class Xenophyophorea (Lemche and Wingstrand 1959, Tendal 1985, Warén and Hain 1992).

Little is known about the foraging tactics adopted by the group, but it is fairly accepted that their cusps are used as pallets to scrape the organo-mineral surface layer of ferromanganese nodules. They feed on protozoans, radiolarians, diatoms, foraminifera and sponges (Urgorri et al. 2005, Lindberg 2009).

\section{SCAPHOPODA FORAGING BEHAVIOR}

The Scaphopoda are a class of exclusively marine and infaunal mollusks, well-known for the muscular foot used for digging, univalve tusk shaped shell with two apertures, and for tactile organs named captacula, which are used in the feeding process (Reynolds and Okusu 1999). The researches regarding their feeding behavior are very limited, but the few species studied in this respect suggest the existence of a pattern.

Among the members of the order Dentaliida, the foraging process begins with the opening of muscle sheath of the mantle cavity, allowing the exit of the foot and the captacula. With the tapered part of the foot, the scaphopod creates a spacious and almost spherical cavity, and begins, with the aid of the captacula, to probe the sediment by fumbling the particles with their bulbous tips and capturing them through long cilia situated in the alveoli of these structures (Morton 1959, Dinamani 1964a, 1964b, Gainey 1972).

The particles are transported to the mouth in three possible ways: by being captured or trapped by the tip of captacula by simple adhesion or wrapping (Morton 1959, Poon 1987, Shimek 1988); one group of captacula can be used together to capture larger prey (Dinamani 1964b), or the particles may be carried from the bulb to the base of the captacula by ciliary action - in this case the existence of a ciliary band at the filaments of the captacula is needed (Gainey 1972). The particles are gathered into a furrow on the dorsal surface of the foot, behind the podal lobes. Repeated upthrows are carried out in order to bring the set of collected particles nearer the labial palps which, on the other hand, evert and select the material to be intaken. After some time, the mantle cavity is opened, allowing the expulsion of rejected material (Gainey 1972, Bilyard 1974, Byrum and Ruppert 1994, Reynolds 2002).

In the order Gadilida, the behavior pattern is a little different. After excavation, the animal expands and retracts its discoid foot edge, creating a feeding cavity similar to the one constructed by dentaliids, but of smaller size. Still within the shell, the proboscis 
are extended to the previous opening, from where captacula emerge and, while penetrating in the sediment, are followed by more captacula, which go down and pass their cilia along the filaments that are probing the substrate. Finally, the captacula are then taken towards the oral cavity with or without adhering particles; the selection occurs through the labial palps and the ingestion process is completed (Davis 1968, Poon 1987).

According to Gainey (1972), once the feeding cavity has been sufficiently used, the animal must seek a new foraging area. Therefore, it occurs with the extension of the mantle cavity followed by expansion of its epipodial and central lobes; muscle contraction generates circular upthrows which cause rearward movements; foot lobes get less swollen and the shell becomes responsible for the anchoring function. This process repeats itself over and over again, with small angle variations, but always taking the scaphopod to a new foraging area. There are some evidences that the Scaphopoda prefer eating foraminifera and small heterotrophic animals (Bilyard 1974, Shimek 1990, Glover et al. 2003, Gudmundsson et al. 2003). Apparently, once the scaphopod eats the foraminifera, it preferentially breaks the chambers of the last part of its shell, but the reason is not well known (Langer et al. 1995).

\section{CEPHALOPODA FORAGING BEHAVIOR}

Cephalopoda is a very diverse and successful group that occupies a variety of niches in the marine environment. Its members belong to one of two subclasses: Nautiloidea, which includes only two remaining genera with external shell, and Coleoidea, comprising shelless or internally shelled mollusks, such as octopuses, cuttlefishes and squids (Teichert 1988).

The Coleioidea are active predators that capture their preys in many different ways. Among the octopus (Octopodiformes), the most used senses during foraging are touch and sight, therefore there are two main tactics inherent to any individuals in this group and known by groping and pouncing (Hartwick et al. 1981, Huffard 2007). Groping is the tactile detection without a specific object, when the animal passes the tentacles on the sediment, algae banks, inside cracks and other substrates until prey is eventually found. On the other hand, pouncing is an aimed tactic, in which the individual removes a specific object from its place, completely stretching its arms. The animal involves the object and uses the tips of the tentacles to hunt around and underneath it (Forsythe and Hanlon 1997).

When the detection is purely visual, the swimming direction (back to front) is changed. Arms are pointed out in the direction of the prey and the swimming speed is slightly reduced near the same (Villanueva et al. 1996). Finally, the prey is subdued and eaten or if they have rigid bodies and protection structures, as in bivalves, gastropods and crustaceans, the animal needs to play two more complementary tactics. Shell and carapace perforation may happen by the action of the beak and the inoculation of toxins present in saliva, which relax the muscle attachments of the prey, allowing the extraction and ingestion of its body. The prey may also be removed by force (Grisley et al. 1996, Cortez et al. 1998, Fiorito and Gherardi 1999, Šifner and Vrgoè 2009). It often happens with females of the species Octupus vulgaris, that, during spawning or nesting do not produce toxins (Wodinsky 1978).

With this prospect, it is worth mentioning a few exceptions, such as a species of the Pacific Wunderpus photogenicus, which probe the muddy sediment with its arms, capturing the preys using the suckers at its tips. Another strategy adopted by this animal is the extension of the arms and the membrane between them over an area of sediment, building a "net" to capture any hidden prey in the substrates (Hochberg et al. 2006). While studying larvae of Octopus dofleini, Marliave (1981) noticed a predatory behavior pattern, in which the contact between the larval mantle and the krill prompted reflex movements and the larvae would start spinning their bodies and adhering their tentacles to the water surface film, keeping a backward posture; the siphon was then used to create lateral movements, in order to bring the krill down to the bottom, where the ingestion occurred. Another exception was observed by Voight (2008), where, using submersible vehicles, deep sea octopods were seen using specifically the middle portion of their arms in search of infaunal prey, while their dorsal arms were extended in the water column, probably in search of smaller animals. Furthermore, Scheel and Anderson (2012) observed that the species Enteroctopus dofleini learned to forage on fishing nets. 
Squids and cuttlefishes (Decapodiformes) show a more aggressive behavior, being considered great hunters. The squid have nocturnal habits and hunts in shallow waters (Markaida and Sosa-Nishizaki 2003). Their attack happens as follows: they approach the prey, extending their arms sideways and eventually emitting a flash of bioluminescence of their tips. The animal is captured with the suckers of their two tentacles, that are used to bring the prey into their arms, holding it so that the intake occurs. On the other hand, when the prey is bigger and faster, the squid chases until they can catch it with their arms and without using the tentacles (Squires and Barragan 1979, Kubodera et al. 2007).

An exception is the pygmy squid, Idiosepius paradoxus, that uses its arms to capture and paralyze the prey by its posterior portion, extending its buccal mass toward the preys and releasing enzymes for external digestion. Finally, the intake of semi-digested meat occurs, in a process that does not involve biting (Kasugai et al. 2004). Another special case is the jumbo squid (Dosidicus gigas), that is considered to have no fixed foraging strategy, changing its tactics according to modifications on the environment (Lorrain et al. 2011).

The cuttlefish is a diurnal hunter (Aitken et al. 2005) and has its attacking behavior divided into three phases: observation, positioning and seizure (Adamo et al. 2006). In the first phase, the animal undergoes color changes, elevation of the first and second pair of arms, head and eye movement and change of direction until the prey is ahead. In the second stage, the animal approaches or moves away from the prey slowly, so that the "striking distance" is achieved. In the third and final phase, the two tentacles are ejected in a split second, capturing the prey by suction terminals and bringing it to its mouth. Shrimps and crabs are poisoned and die within a maximum of 9 seconds (Messenger 1968, 1973, Tang and Khoo 1974, Cole and Adamo 2005). In their study, Darmaillacq et al. (2004) discovered that once the cuttlefish experience inedible prey, they learn to recognize and avoid it for a long time.

Unlike the representatives of the subclass Coleoidea, the Nautiloidea are not big predators but scavengers of nocturnal habits (Ward and Wicksten 1980, Westermann and Schipp 1998). The detection of food can occur randomly during a behavior called Cat's Whiskers Pose, in which 3 or 4 pairs of tentacles are extended radially, while the animal swims upwards to the water column and descends towards the bottom, maintaining the tentacles' position, which allows the perception of any food items around it (Haven 1972). They also locate their food through a combination of touch and smell, following a boost from some distant source of odor. In this case, after leaving the position, they swim towards the possible source of food and extend its tentacles to form the so-called "cone of search". The increase of the breathing movements and the swimming rhythm allows a greater flow of water passing through the ocular tentacles and rhinophore. While swimming forward, backward and making pendular movements, the digital tentacles grope random substrates to find food. Then, the nautilus goes deeper in the water until it is possible to lean over one medium digital tentacle and grab the prey with another one, passing over to the oral tentacle and, finally, to the beak (Wells 1989, Ruth et al. 2002, Westermann and Beuerlein 2005).

\section{CONCLUSIONS, GAPS IN KNOWLEDGE AND FUTURE PERSPECTIVES}

Main hypothesis on interrelationships of basal molluscan groups, Testaria (Taylor 1996, Haszprunar, 2000) and Aculifera (Scheltema 1993), postulated that Solenogastres and Caudofoveata (=Aplacophora) constitute the most basal taxa. In this sense, we can assume that primitive mollusks were wormlike, epifaunal, true predators and/or deposit-feeders. Both hypothesis display Polyplacophora as a result of a new lineage after Aplacophora. Despite the fact that most chitons (=Polyplacophora) are generalist grazers of hard substrata, in this class we observed a variety of feeding habits. Conchifera constitutes the next step (according to Testaria and Aculifera hypothesis) and are represented in this study by Monoplacophora, Scaphopoda and Cephalopoda. Monoplacophora is a basal taxon that presents deposit-feeding habits. Scaphopoda is also a deposit-feeder but presents a specialized organ to detect and capture organic matter on the substratum. Cephalopoda could be treated as sister group of either Gastropoda or Scaphopoda and shows two feeding habits: scavengers and true predators. In general, feeding habits cannot be used to phylogenetic inference, since they are easily influenced by external factors. Furthermore, the degree of variability in feeding habits found within the group could be a direct consequence of huge radiation (see Tables 1-2 for a detailed description). 


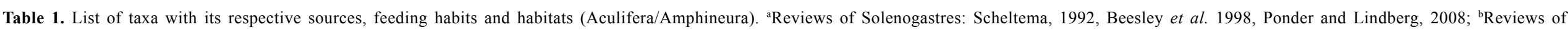
Caudofoveata: Beesley et al. 1998, Glaubrecht, 2005; 'Reviews of Polyplacophora: Boyle, 1977, Eerisse and Reynolds, 1994, Sirenko, 2000.

\begin{tabular}{|c|c|c|c|}
\hline TAXA & SOURCES & FEEDING HABIT & НABITAT \\
\hline \multicolumn{4}{|l|}{ SOLENOGASTRES ${ }^{a}$} \\
\hline \multicolumn{4}{|l|}{ Cavibelonia } \\
\hline \multicolumn{4}{|l|}{ Epimeniidae } \\
\hline Epimenia australis (Thiele, 1897) & Scheltema and Jebb 1994 & True predators / Active hunters & Continental shelf \\
\hline Epimenia babai Salvini-Plawen, 1997 & Okuso and Giribet 2003 & True predators / Active hunters & Continental shelf \\
\hline \multicolumn{4}{|l|}{ Simrothiellidae } \\
\hline Helicoradomenia spp. & Scheltema et al. 2003 & True predators / Active hunters & Hydrothermal vent \\
\hline Helicoradomenia sp. & Okuso and Giribet 2003 & True predators / Active hunters & Hydrothermal vent \\
\hline \multicolumn{4}{|l|}{ Pholidos kepia } \\
\hline \multicolumn{4}{|l|}{ Meiomeniidae } \\
\hline Meioherpia stygalis Salvini-Plawen and Sterrer, 1985 & Okuso and Giribet 2003 & True predators / Active hunters & Littoral \\
\hline Meiomenia arenicola Salvini-Plawen and Sterrer, 1985 & Morse and Norenburg 1992 & True predators / Active hunters & Littoral \\
\hline \multicolumn{4}{|l|}{ CAUDOFOVEATA $^{\mathrm{b}}$} \\
\hline \multicolumn{4}{|l|}{ Chae todermatida } \\
\hline \multicolumn{4}{|l|}{ Chaetode rmatidae } \\
\hline Chaetoderma nitidulum Lovén, 1844 & Ponder and Lindberg 2008 & Deposit-feeder & Littoral - Bathyal \\
\hline \multicolumn{4}{|l|}{ Prochae tode rmatidae } \\
\hline Prochaetoderma boucheti Scheltema and Ivanov, 2000 & Scheltema and Ivanov 2000 & Deposit-feeder & Mesopelagic \\
\hline Prochaetoderma raduliferum (Kowalewsky, 1901) & Scheltema and Ivanov 2000 & Deposit-feeder & Littoral - Continental shelf \\
\hline Spathoderma alleni Scheltema and Ivanov, 2000 & Scheltema and Ivanov 2000 & Deposit-feeder & Littoral - Bathyal \\
\hline \multicolumn{4}{|l|}{ POLYPLACOPHORA } \\
\hline \multicolumn{4}{|l|}{ Chitonida } \\
\hline \multicolumn{4}{|l|}{ Acanthochitonidae } \\
\hline Acanthochitona garnoti (Blainville, 1825) & Cretchley et al. 1997 & True predators / Active hunters & Littoral \\
\hline Acanthopleura gemmata (Blainville, 1825) & Hulings 1991, Barbosa et al. 2008 & True predators / Active hunters & Littoral \\
\hline
\end{tabular}




\begin{tabular}{|c|c|c|c|}
\hline TAXA & SOURCES & FEEDING HABIT & НАВITAT \\
\hline Acanthopleura hirtosa (Blainville, 1825) & Shaw et al. 2002 & True predators / Active hunters & Littoral \\
\hline Notoplax speciosa (H. Adams, 1861) & Beesley et al. 1998 & True predators / Active hunters & Littoral \\
\hline Craspedochiton spp. & Eernisse 2007 & True predators / Sit-and-wait & Littoral \\
\hline \multicolumn{4}{|l|}{ Is chnochitonidae } \\
\hline Lepidochitona dentiens (Gould, 1846) & Piercy 1987 & True predators / Active hunters & Littoral \\
\hline Stenoplax heathiana Berry, 1946 & Putman 1990 & True predators / Active hunters & Littoral \\
\hline Ischnochiton albus (Linnaeus, 1767) & Langer 1983 & & Littoral \\
\hline \multicolumn{4}{|l|}{ Loricidae } \\
\hline Loricella angasi & Eernisse 2007 & True predators / Sit-and-wait & Continental shelf \\
\hline \multicolumn{4}{|l|}{ Mopaliidae } \\
\hline Mopalia ciliata (Soweby, 1840) & Piercy 1987 & True predators / Active hunters & Littoral \\
\hline Mopalia hindsii (Soweby MS, Reeve, 1847) & Piercy 1987, Beesley et al. 1998 & True predators / Active hunters & Littoral \\
\hline Mopalia muscosa (Gould, 1846) & Piercy 1987 & True predators / Active hunters & Littoral \\
\hline Placiphorella sp. & Clark 1994 & True predators / Sit-and-wait & Littoral \\
\hline Placiphorella velata (Carpenter MS, Dall, 1879) & McLean 1962 & True predators / Sit-and-wait & Littoral \\
\hline Tonicella lineata (Wood, 1815) & Barnes 1972, Piercy 1987 & True predators / Active hunters & Littoral \\
\hline Tonicella marmorea (O. Fabricius, 1780) & Langer 1983 & True predators / Active hunters & Littoral \\
\hline Tonicella rubra (Linnaeus, 1767) & Langer 1983 & True predators / Active hunters & Littoral \\
\hline Katharina tunicata (Wood, 1815) & Piercy 1987 & True predators / Active hunters & Littoral \\
\hline \multicolumn{4}{|l|}{ Lepidople urida } \\
\hline \multicolumn{4}{|l|}{ Leptochitonidae } \\
\hline Leptochiton vietnamensis Sirenko, 1998 & Sirenko 1998 & True predators / Active hunters & Continental shelf - Bathyal \\
\hline Leptochiton vitjazae (Sirenko, 1977) & Beesley et al. 1998 & Deposit-feeder & Abyssal \\
\hline \multicolumn{4}{|l|}{ Abys sochitonidae } \\
\hline Xylochiton xylophagus Gowlett-Holmes and Jones, 1992 & Beesley et al. 1998 & Deposit-feeder & Abyssal \\
\hline
\end{tabular}




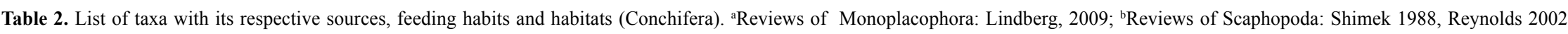

\begin{tabular}{|c|c|c|c|}
\hline TAXA & SOURCES & FEEDING HABIT & НАBITAT \\
\hline \multicolumn{4}{|l|}{ MONOPLACOPHORA ${ }^{\mathrm{a}}$} \\
\hline \multicolumn{4}{|l|}{ Tryblidiida } \\
\hline \multicolumn{4}{|l|}{ Neopilinidae } \\
\hline Laevipilina antarctica Warén and Hain, 1992 & Warén and Hain 1992 & Deposit-feeder & Bathyal - Abyssal \\
\hline $\begin{array}{l}\text { Laevipilina cachuchensis Urgorri, García-Álvarez and Luque, } \\
2005\end{array}$ & Urgorri et al. 2005 & Deposit-feeder & Bathyal \\
\hline Micropilina arntzi Warén and Hain, 1992 & Warén and Hain 1992 & Deposit-feeder & Continental shelf - Bathyal \\
\hline Neopilina galatheae Lemche, 1957 & Lemche and Wingtrand 1959, Tendal 1985 & Deposit-feeder & Abyssal \\
\hline \multicolumn{4}{|l|}{ SCAPHOPODA $^{\mathrm{b}}$} \\
\hline \multicolumn{4}{|l|}{ Dentaliida } \\
\hline \multicolumn{4}{|l|}{ Dentaliidae } \\
\hline Dentalium conspicuum Melvill, 1897 & Dinamani 1964a, 1964b & Deposit-feeder & Littoral \\
\hline Dentalium eboreum Conrad, 1846 & Gainey 1972 & Deposit-feeder & Littoral \\
\hline Dentalium entale stimpsoni Henderson, 1920 & Bilyard 1974 & Deposit-feeder & Continental shelf - Bathyal \\
\hline Dentalium entalis Linnaeus, 1758 & Morton 1959 & Deposit-feeder & Littoral \\
\hline Dentalium pseudohexagonum Henderson, 1920 & Gainey 1972 & Deposit-feeder & Littoral \\
\hline Dentalium rectius Carpenter, 1864 & Shimek 1990 & Deposit-feeder & Continental shelf - Bathyal \\
\hline Fissidentalium megathyris (Dall, 1890) & Langer et al. 1995 & Deposit-feeder & Bathyal \\
\hline Graptacme calamus (Dall, 1889) & Byrum and Ruppert 1994 & Deposit-feeder & Littoral \\
\hline \multicolumn{4}{|l|}{ Laevidentaliidae } \\
\hline Laevidentalium lubricatum (Sowerby, 1860) & Glover et al. 2003 & Deposit-feeder & Littoral \\
\hline \multicolumn{4}{|l|}{ Gadilida } \\
\hline \multicolumn{4}{|l|}{ Gadilidae } \\
\hline Cadulus aberrans Whiteaves, 1887 & Shimek 1990 & Deposit-feeder & Continental shelf \\
\hline Cadulus quadridentatus Dall, 1881 & Davis 1968 & Deposit-feeder & Continental shelf \\
\hline Cadulus tomiei (Dall, 1897) & Poon 1987 & Deposit-feeder & Continental shelf - Bathyal \\
\hline
\end{tabular}




\begin{tabular}{lll}
\hline TAXA & SouRCES & FEEDING HABIT \\
\hline $\begin{array}{l}\text { Polyschides olivi (Scacchi, 1835) } \\
\text { Siphonodentalium lobatum (G.B. Sowerby II, 1860) }\end{array}$ & Gudmundsson et al. 2003 & Deposit-feeder \\
Pulse llidae & Gudmundsson et al. 2003 & Deposit-feeder \\
Pulsellum affine (M. Sars, 1865) & & Bathyal \\
Pulsellum salishorum Marshall, 1980 & Gudmundsson et al. 2003 & Deposit-feeder \\
Pulsellum teres (Jeffreys, 1883) & Shimek 1990 & Deposit-feeder \\
\end{tabular}

\section{CEPHALOPODA}

\section{Octopoda}

\section{Octopodidae}

Abdopus aculeatus (d'Orbigny, 1834)

Huffard 2007

Voight 2008

Grisley et al. 1996

Eledone cirrhosa (Lamarck, 1798)

Eledone moschata (Lamarck, 1798)

Enteroctopus dofleini (Wülker, 1910)

Graneledone sp.

Octopus cyanea Gray, 1849

Octopus mimus Gould, 1852

Octopus vulgaris Cuvier, 1797

Vulcanoctopus hydrothermalis Gonzalez and Guerra in Gonzalez et al. 1998

Wunderpus photogenicus Hochberg, Norman and Finn, 2006

\section{Oegopsida}

\section{Ommastrephidae}

Dosidicus gigas (d'Orbigny, 1835)

\section{Octopote uthidae}

Taningia danae Joubin, 1931 Anderson 2012

Voight 2008

Cortez et al. 1998

Gherardi 1999

Voight 2008
Šifner and VrgoČ 2009

Hartwick et al. 1981, Marliave 1981, Scheel and

Forsythe and Hanlon 1997

Wodinsky 1978, Villanueva et al. 1996, Fiorito and True predators / Active and Sit-and-

Hochberg et al. 2006

Markaida and Sosa-Nishizaki 2003, Lorrain et al. True predators**

Epipelagic - Mesopelagic

True predators / Active hunters

True predators / Active hunters

True predators / Active hunters

True predators / Active hunters

True predators / Active hunters

True predators / Active hunters

True predators / Active hunters

True predators / Active hunters

Littoral

Continental shelf - Bathyal

Continental shelf - Bathyal

Continental shelf - Bathyal

Littoral - Continental shelf

Bathyal - Abyssal

Littoral

Littoral

wait

True predators / Active hunters

True predators / Active and Sit-and-

wait

Continental shelf

True predators / Active hunters

Mesopelagic 


\begin{tabular}{|c|c|c|c|}
\hline TAXA & SOURCES & FEEDING HABIT & НАBITAT \\
\hline \multicolumn{4}{|l|}{ Idios e piida } \\
\hline \multicolumn{4}{|l|}{ Idiosepiidae } \\
\hline Idiosepius paradoxus (Ortmann, 1888) & Kasugai et al. 2004 & True predators / Active hunters & Littoral \\
\hline \multicolumn{4}{|l|}{ Myopsida } \\
\hline \multicolumn{4}{|l|}{ Loliginidae } \\
\hline Lolliguncula panamensis Berry, 1911 & Squires and Barragan 1979 & True predators / Active hunters & Littoral \\
\hline \multicolumn{4}{|l|}{ Sepiida } \\
\hline \multicolumn{4}{|l|}{ Sepiidae } \\
\hline Sepia apama Gray, 1849 & Aitken et al. 2005 & True predators / Sit-and-wait & Littoral - Continental shelf \\
\hline Sepia officinalis Linnaeus, 1758 & $\begin{array}{l}\text { Messenger 1968, Messenger 1973, Darmaillacq et } \\
\text { al. 2004, Cole and Adamo 2005, Adamo et al. } 2006\end{array}$ & True predators / Sit-and-wait & Continental shelf \\
\hline Sepiella inermis (Van Hasselt, 1835) & Tang and Khoo 1974 & True predators / Sit-and-wait & Continental shelf \\
\hline \multicolumn{4}{|l|}{ Nautiloidea } \\
\hline \multicolumn{4}{|l|}{ Nautilidae } \\
\hline Nautilus macromphalus Sowerby, 1848 & $\begin{array}{l}\text { Ward and Wicksten 1980, Westermann and Schipp } \\
1998\end{array}$ & Scavengers & Mesopelagic \\
\hline Nautilus pompilius Linnaeus, 1758 & $\begin{array}{l}\text { Haven 1972, Westermann and Schipp 1998, Ruth et } \\
\text { al. 2002, Westermann and Beuerlein } 2005\end{array}$ & Scavengers & Mesopelagic \\
\hline Nautilus sp. & Wells 1989 & Scavengers & Mesopelagic \\
\hline
\end{tabular}


The non-selective deposit-feeding is the simplest feeding strategy within the benthic invertebrates, although it is absent in Mollusca. The second simplest feeding method is the selective deposit-feeding, which is found between the representatives of Caudofoveata, Monoplacophora and Scaphopoda. More complex strategies were developed by true predators, such as solenogasters, cephalopods and polyplacophorans, and suspension-feeders, such as bivalves (not included in this study). Amongst true predators, it is possible to highlight the ones that (1) creep on substrata searching for specific prey, not eating the entire individual and (2) the ones that actively subdue and eat the entire prey. It is possible to observe active hunters in both types of true predators, but only the second group comprises sit-and-wait hunters. Nautiloids are exceptions amongst cephalopods because of their scavenger feeding habit; therefore, they fit in the deposit-feeders category.

The highest percentage $(c a .58 \%, \mathrm{n}=50)$ of the study was conducted in shallow waters/continental shelf taxa while $26 \%(\mathrm{n}=26)$ were conducted in deep waters taxa. Nearly $15 \%(n=13)$ of the studied taxa presented wide bathymetric range, occurring from shallow to great depths. Solenogastres, in spite of their high diversity at great depths, have been mostly studied at shallow waters. Additionally, we observed almost none studies about Polyplacophora from deep waters. These results showed that scarce knowledge about deep waters represents an important paradigm.

Within the studied classes, Aplacophora and Monoplacophora were the ones with less detailed descriptions of their feeding behavior. Polyplacophora and Scaphopoda seemed to be relatively well studied as a result of the effort of a few expert researchers. Although Cephalopoda was the class with the highest number of studies, most of the covered taxa was repeatedly investigated and presents economic value (e.g. Fisheries species). We showed that the major gaps in the knowledge of feeding habits are concentrated to basal taxa of the phylum Mollusca and from deep water habitats.

ACKNOWLEDGEMENTS: We would like to thank professors Dr. Maria Alice dos Santos Alves and Dr. Natalie Freret Meurer (Programa de PósGraduação em Ecologia e Evolução da Universidade Estadual do Rio de Janeiro) for coming up with the concept of the study; Dr. Jaime Alberto Jardim Gomes (MZUSP) for collaborating in the research of the class Polyplacophora; the staff of Laboratório de
Malacologia and the library of the Museu Nacional do Rio de Janeiro for providing access to "The Veliger" journal. We would also like to thank Tarciso Almeida de Araújo, Flávia Fernandes, Leonardo Santos de Souza and Igor Christo Miyahira, our colleagues at the Laboratório de Zoologia de Invertebrados Marinhos (UNIRIO), for helping us in the search for articles; and the journalist Karla Menezes for translating this review.

\section{REFERENCES}

Adamo, S. A., K. Ehgoetz, C. Sangster, and I. Whitehorne. 2006. Signaling to the enemy? Body pattern expression and its response to external cues during hunting in the cuttlefish Sepia officinalis (Cephalopoda). Biological Bulletin 210:192-200.

Aitken, J. P., R. K. O’Dor, and G. D. JACKSON. 2005. The secret life of the giant Australian cuttlefish Sepia apama (Cephalopoda): behaviour and energetics in nature revealed through radio acoustic positioning and telemetry (RAPT). Journal of Experimental Marine Biology and Ecology 320:77-91. http:// dx.doi.org/10.1016/j.jembe.2004.12.040

Barbosa, S. S., M. Byrne, and B. P. Kelaher. 2008. Bioerosion caused by foraging of the tropical chiton Acanthopleura gemmata at One Tree Reef, southern Great Barrier Reef. Coral Reefs 27:635-639. http://dx.doi.org/10.1007/s00338-008-0369-4

Barnes, J. R. 1972. Ecology and reproductive biology of Tonicella lineata (Wood, 1815) (Mollusca - Polyplacophora). PhD Thesis. Oregon State University, Corvallis, USA.

Beesley, P. L., G. J. B. Ross, and A. Wells. 1998. Mollusca: the Southern Synthesis. The Fauna of Australia, volume 5. CSIRO Publishing, Melbourne, Australia.

Belovsky, G. E.1978. Diet optimization in a generalist herbivore - moose. Theoretical Population Biology 14:105-134. http://dx.doi.org/10.1016/0040-5809(78)90007-2

Bilyard, G. R. 1974. The feeding habits and ecology of Dentalium entale stimpsoni Henderson (Mollusca: Scaphopoda). The Veliger 17:126-138.

Boyle, P. R. 1977. The physiology and behaviour of chitons (Mollusca: Polyplacophora). Oceanography and Marine Biology. 15:461-509.

Byrum, C. A., and E. E. Ruppert. 1994. The ultrastructure and functional morphology of a captaculum in Graptacme calamus (Mollusca, Scaphopoda). Acta Zoologica 75:37-46. http:// dx.doi.org/10.1111/j.1463-6395.1994.tb00960.x

Caetano, C. H. S., A. D. Pimenta, and R. S. Absalão. 2007. Filo Mollusca. Pages 97-132 in: H. P. Lavrado, and M. S. Viana, editors. Atlas de invertebrados marinhos da região central da zona econômica exclusiva brasileira - parte 1. Museu Nacional, Rio de Janeiro, Brasil.

Clark, R. N. 1994. Review of the genus Placiphorella Dall, 1879, ex Carpenter MS (Polyplacophora: Mopaliidae) with descriptions of two new species. The Veliger 37:290-311.

Cole, P. D. and S. A. Adamo. 2005. Cuttlefish (Sepia officinalis: Cephalopoda) hunting behavior and associative learning. Animal Cognition 8:27-30. http://dx.doi.org/10.1007/s10071-004-0228-9

Cortez, T., B. G. Castro, and A. Guerra. 1998. Drilling behaviour of Octopus mimus Gould. Journal of Experimental Marine Biology and Ecology 224:193-203. http://dx.doi.org/ 10.1016/S0022-0981(97)00198-6

Cretchley, R., A. N. Hodgson, D. R. Gray, and K. Reddy. 
1997. Variation in foraging activity of Acanthochitona garnoti (Mollusca: Polyplacophora) from different habitats. South African Journal of Zoology 32:59-63.

Darmaillacq, A. S., L. Dickel, M. P. Chichery, V. Agin, and R. Chichery. 2004. Rapid taste aversion learning in adult cuttlefish, Sepia officinalis. Animal Behaviour 68:1291-1298. http:// dx.doi.org/10.1016/j.anbehav.2004.01.015

Davis, J. D. 1968. A note on the behaviour of the scaphopod, Cadulus quadridentatus (Dall) 1881. Proceedings of the Malacological Society of London 38:135-138.

Dinamani, P. 1964a. Burrowing behavior of Dentalium. Biological Bulletin 126:28-32.

Dinamani, P. 1964b. Feeding in Dentalium conspicuum. Proceedings of the Malacological Society of London 36:1-6. Eernisse, D. J. 2007. Chitons. Pages 127-133 in: M. W. Denny, and S. D. Gaines, editors. Encyclopedia of tidepools and rock shores. University of California Press, Berkeley, USA.

Eernisse, D. J., and P. D. Reynolds. 1994 Polyplacophora. Pages. 56-110 in: F. W. Harrison, and A. J. Kohn, editors. Microscopic Anatomy of Invertebrates, Volume 5, Mollusca 1. Wiley-Liss, New York, USA.

Fiorito, G., and F. Gherardi. 1999. Prey-handling behaviour of Octopus vulgaris (Mollusca, Cephalopoda) on bivalve preys. Behavioural Processes 46:75-88. http://dx.doi.org/ 10.1016/S0376-6357(99)00020-0

Forsythe, J. W., and R. T. Hanlon. 1997. Foraging and associated behavior by Octopus cyanea Gray, 1849 on a coral atoll, French Polynesia. Journal of Experimental Marine Biology and Ecology 209:15-31. http://dx.doi.org/10.1016/S00220981(96)00057-3

Gainey, L. F. 1972. The use of the foot and the captacula in the feeding of Dentalium. The Veliger 15:29-34.

Glaubrecht, M., L. Maitas, and L. Salvini-Plawen. 2005. Aplacophoran Mollusca in the Natural History Museum Berlin. An annotated catalogue of Thiele's type specimens, with a brief review of "Aplacophora" classification. Mitteilungen aus dem Museum für Naturkunde in Berlin Zoosystematics and Evolution 81:145-166.

Glover, E., J. Taylor, and J. Whittaker. 2003. Distribution, abundance and foraminiferal diet of an intertidal scaphopod, Laevidentalium lubricatum, around the Burrup Peninsula, Dampier, Western Australia. Pages 225-240. in: F. E. Wells, D. I. Walker, and D. S. Jones, editors. The Marine Flora and Fauna of Dampier. Western Australian Museum, Perth, Australia.

Greene, C. H. 1986. Patterns of prey selection: implications of predator foraging tactics. The American Naturalist 128:824-839.

Grisley, M. S., P. R. Boyle, and L. N. Key. 1996. Eye puncture as a route of entry for saliva during predation on crabs by the octopus Eledone cirrhosa (Lamarck). Journal of Experimental Marine Biology and Ecology 202:225-237. http:// dx.doi.org/10.1016/0022-0981(96)00035-4

Gudmundsson, G., K. Engelstad, G. Steiner, and J. Svavarsson. 2003. Diets of four deep-water scaphopod species (Mollusca) in the North Atlantic and the Nordic Seas. Marine Biology 42:1103-1112.

Hartwick, B., L. Tulloch, and S. Macdonalds. 1981. Feeding and growth of Octopus dofleini (Wülker). The Veliger 24:129-138.

Haszprunar, G. 2000. Is the Aplacophora monophyletic? A cladistic point of view. American Malacological Bulletin 15:115-130 Haszprunar, G. 2001. Mollusca (Molluscs). eLS. http:// dx.doi.org/10.1038/npg.els.0001598

Haven, N. 1972. The ecology and behavior of Nautilus pompilius in the Philippines. The Veliger 15:75-80.

Hochberg, F. G., M. D. Norman, and J. Finn. 2006. Wunderpus photogenicus $\mathrm{n}$. gen. and sp., a new octopus from the shallow waters of the Indo-Malayan Archipelago (Cephalopoda: Octopodidae). Molluscan Research 26:128-140.

Huffard, C. L. 2007. Ethogram of Abdopus aculeatus (d'Orbigny, 1834) (Cephalopoda: Octopodidae): Can behavioural characters inform octopodid taxonomy and systematics? Journal of Molluscan Studies 73:185-193. http://dx.doi.org/10.1093/ mollus/eym015

Hugie, D. M. 2003. The waiting game: a "battle of waits" between predator and prey. Behavioral Ecology 14:807-817. http:/ /dx.doi.org/10.1093/beheco/arg054

Hughes, R. 2009. Diet Selection: An Interdisciplinary Approach to Foraging Behaviour. John Wiley and Sons, New Jersey, USA.

Hulings, N. C. 1991. Activity patterns and homing of Acanthopleura gemmata (Blainville, 1825) (Mollusca: Polyplacophora) in the rocky intertidal of the Jordan Gulf of Aqaba. The Nautilus 105:16-25.

Kasugai, T., S. Shigeno, and Y. Ikeda. 2004. Feeding and external digestion in the japanese pygmy squid Idiosepius paradoxus (Cephalopoda: Idiosepiidae). Journal of Molluscan Studies, 70:231-236. http://dx.doi.org/10.1093/mollus/70.3.231

Kubodera, T., Y. Koyama, and K. Mori. 2007. Observations of wild hunting behaviour and bioluminescence of a large deep-sea, eight-armed squid, Taningia danae. Proceedings of the Royal Society B 274:1029-1034. http://dx.doi.org/10.1098/ rspb.2006.0236

Lamprell, K. L., and A. M. Scheltema. 2001. Mollusca: Aplacophora, Polyplacophora, Scaphopoda, Cephalopoda. Volume. 17. Csiro Publishing, Melbourne, Australia.

Langer, M. R., J. H. Lipps, and G. Moreno. 1995. Predation on foraminifera by the dentaliid deep-sea scaphopod Fissidentalium megathyris. Deep-Sea Research I 42:849-857. http:/ /dx.doi.org/10.1016/0967-0637(95)00025-2

Langer, P. D. 1983. Diet analysis for three subtidal coexisting chitons from the Northwestern Atlantic (Mollusca: Polyplacophora). The Veliger 25:370-372.

Latyshev, N. A., A. S. Khardin, S. P. Kasyanov, and A. M. B. Ivanova. 2004. A study on the feeding ecology of chitons using analisys of gut contents and fatty acid markers. Journal of Molluscan Studies 70:225-230. http://dx.doi.org/10.1093/mollus/ 70.3.225

Lemche, H., and K. Wingstrand. 1959. The anatomy of Neopilina galatheae Lemche, 1957 (Mollusca, Tryblidiacea). Galathea Report, 3:9-72.

Lima, S. L., and L. M. Dill. 1990. Behavioral decisions made under the risk of predation: a review and prospectus. Canadian Journal of Zoology 68:619-640. http://dx.doi.org/ 10.1139/z90-092

Lindberg, D. L. 2009. Monoplacophorans and the origin and relationships with mollusks. Evolution: Education and Outreach 2:191-203. http://dx.doi.org/10.1007/s12052-009-0125-4

Lorrain, A., J. Argüelles, A. Alegre, A. Bertrand, J. M. Munaron, P. Richard, and Y. Cherel. 2011. Sequential isotopic signature along gladius highlights contrasted individual foraging strategies of jumbo squid (Dosidicus gigas). PLoS ONE 6:e22194 http://dx.doi.org/10.1371/journal.pone.0022194

Lowenstam, H. A. 1978. Recovery, behaviour and 
evolutionary implications of live Monoplacophora. Nature 273:231-232. http://dx.doi.org/10.1038/273231a0

MacAArthur, R. H., and E. R. Pianka. 1966. On optimal use of a patchy environment. The American Naturalist 100:603-609.

Markaida, U., and O. Sosa-Nishizaki. 2003. Food and feeding habits of jumbo squid Dosidicus gigas (Cephalopoda: Ommastrephidae) from the Gulf of California, Mexico. Journal of the Marine Biological Association of the UK, 83:507-522. http://dx.doi.org/10.1017/S0025315403007434h

Marliave, J. B. 1981. Neustonic feeding in early larvae of Octopus dofleini (Wülker). The Veliger 23:350-351.

Martins, I. X. 2008. Análise cladística dos Caudofoveata (Mollusca) e taxonomia das espécies brasileiras. $\mathrm{PhD}$ Thesis. Universidade Federal da Paraíba, João Pessoa, Brasil.

McLean, J. A. 1962. Feeding behaviour of the chiton Placiphorella. Proceedings of the Malacological Society of London 35:23-26.

Messenger, J. B. 1968. The visual attack by the cuttlefish, Sepia officinalis. Animal Behaviour 16:342-357. http://dx.doi.org/ 10.1016/0003-3472(68)90020-1

Messenger, J. B. 1973. Learning in the cuttlefish, Sepia. Animal Behaviour 21:801-826. http://dx.doi.org/10.1016/S00033472(73)80107-1

Morse, P. M., and J. P. Norenburg. 1992. Observations on and redescription of Meiomenia arenicola Salvini-Plawen, 1985 (Mollusca: Aplacophora), an interstitial Solenogaster from Fort Pierce, Florida. Proceedings of the Biological Society of Washington 105:674-682.

Morton, J. E. 1959. The habits and feeding organs of Dentalium entalis. Journal of the Marine Biological Association of the UK 38:225-238. http://dx.doi.org/10.1017/ S0025315400006032

O'Brien,W. J., H. I. Browman, and B. I. Evans. 1990. Search strategies of foraging animals. American Scientist 78:152-160.

Odum, E. P., and G. W. Barret. 2011. Fundamentos de ecologia. 5a edição. Cengage Learning, São Paulo, Brasil.

Okusu, A., and G. Giribet. 2003. New 18S rRNA sequences from neomenioid aplacophorans and the possible origin of persistent exogenous contamination. Journal of Molluscan Studies 69:385-387. http://dx.doiorg/10.1093/mollus/69.4.385

Petchey, O. L., P. A. Berckerman, O. J. Riley, and H. P. Warren. 2008. Size, foraging, and food web structure. Proceedings of the National Academy of Sciences 105:4191-4196. http:// dx.doi.org/10.1073/pnas.0710672105

PIERCY, R. D. 1987. Habitat and food preferences in six Eastern Pacific chiton species (Mollusca: Polyplacophora). The Veliger 29:388-393.

Pyke, G. H., H. R. Pulliam, and E. L. Charnov. 1977. Optimal foraging: a selective review of theory and tests. Quarterly Review of Biology 52:137-154. http://dx.doi.org/10.1086/409852

Ponder, W. F., and D. R. Lindberg. 2008. Phylogeny and Evolution of the Mollusca. University of California Press, California, USA.

Poon, P. A. 1987. The diet and feeding behaviour of Cadulus tolmiei Dall. 1897 (Scaphopoda: Siphonodentalioida). The Nautilus 101:88-92.

Putman, B. F. 1990. The diet and feeding selectivity of the chiton Stenoplax heathiana Berry, 1946 (Mollusca : Polyplacophora). The Veliger 33:372-374.

Reynolds, P. D. 2002. The Scaphopoda. Advances in Marine Biology 42:137-236. http://dx.doi.org/10.1016/s00652881(02)42014-7
Reynolds, P. D. and Okusu, A. 1999. Phylogenetic relationships among families of the Scaphopoda (Mollusca). Zoological Journal of the Linnean Society 126:131-154. http:// dx.doi.org/10.1111/j.1096-3642.1999.tb00151.x

Ruth, P., H. Schimdtberg, B. Westermann, and R. Schipp. 2002. The sensory epithelium of the tentacles and the rhinophore of Nautilus pompilius L. (Cephalopoda, Nautiloidea). Journal of Morphology 251:239-255. http://dx.doi.org/10.1002/jmor.1086

Scharf, I., Y. Lubin, and O. Ovadia. 2011. Foraging decisions and behavioural flexibility in trap-building predators: a review. Biological Reviews 86:626-639. http://dx.doi.org/10.1111/ j.1469-185X.2010.00163.x

Scheel, D., and R. Anderson. 2012 Variability in the Diet Specialization of Enteroctopus dofleini (Cephalopoda: Octopodidae) in the Eastern Pacific Examined from Midden Contents. American Malacological Bulletin 30:267-279. http:// dx.doi.org/10.4003/006.030.0206

Scheltema, A. H. 1992. The Aplacophora: History, taxonomy, phylogeny, biogeography, and ecology. $\mathrm{PhD}$ Thesis.. University of Oslo, Oslo, Noruega.

Scheltema, A. H. 1993. Aplacophora as progenetic aculiferans and the coelomate origin of mollusks as the sister taxon of Sipuncula. The Biological Bulletin 184:57-78.

Scheltema, A. H., and D. L. Ivanov. 2000. Prochaetodermatidae of the Eastern Atlantic Ocean and Mediterranean Sea (Mollusca: Aplacophora). Journal of Molluscan Studies 66:313-362. http://dx.doi.org/10.1093/mollus/66.3.313

Scheltema, A. H., and M. Jabb. 1994. Natural history of a solenogaster mollusc from Papua New Guinea, Epimenia australis (Thiele) (Aplacophora: Neomeniomorpha). Journal of Natural History 28:1297-1318. http://dx.doi.org/10.1080/ 00222939400770661

Scheltema, A. H., K. Kerth, and A. M. Kuzirian. 2003. Original molluscan radula: comparisons among Aplacophora, Polyplacophora, Gastropoda and the Cambrian fossil Wiwaxia corrugata. Journal of Morphology 257:219-245. http:// dx.doi.org/10.1002/jmor.10121

Scheltema, A. H., and C. Schander. 2000. Discrimination and phylogeny of Solenogaster species through the morphology of hard parts (Mollusca, Aplacophora, Neomeniomorpha). Biological Bulletin 198:121-151.

Schoener, T. W. 1971. A theory of feeding strategies. Annual Review of Ecology and Systematics 2:369-404. http:// dx.doi.org/10.1146/annurev.es.02.110171.002101

Schoener, T. W. 1973. Population-growth regulated by intraspecific competition for energy or time: some simple representations. Theoretical Population Biology 4:56-84. http:// dx.doi.org/10.1016/0040-5809(73)90006-3

Schoener, T. W. 1983. Simple models of optimal feedingterritory size - a reconciliation. The American Naturalist 121:608-629.

Schoener, T. W. 1987. Time budgets and territory size: Some simultaneous optimization models for energy maximizers. American Zoologist 27:259- 291. http://dx.doi.org/10.1093/icb/ 27.2.259

Schwabe, E. 2008. A summary of reports of abyssal and hadal Monoplacophora and Polyplacophora (Mollusca). Zootaxa 1866:205-222.

Shaw, J. A., L. R. Brooker, and D. J. Macey. 2002. Radula tooth turnover in the chiton Acanthopleura hirtosa (Blainville, 1825) (Mollusca: Polyplacophora). Molluscan Research 22:9399. http://dx.doi.org/10.1071/MR02005 
Shimek, R. L. 1988. The functional morphology of scaphopod captacula. The Veliger 30:213-221.

Shimek, R. L. 1990. Diet and habitat utilization in a Northeastern Pacific Ocean scaphopod assemblage. American Malacological Bulletin 7:147-169.

Šifner, S. K., and N. Vrgoè, N. 2009.Diet and feeding of the musky octopus, Eledone moschata, in the northern Adriatic Sea. Journal of the Marine Biological Association of the United Kingdom 89:413-419. http://dx.doi.org/10.1017/ S0025315408002488

Sirenko, B. I. 1998. One more deep-water chiton Lepidochiton vietnamensis sp. nov. (Mollusca, Polyplacophora) living and feeding on sunken wood from South China Sea. Ruthenica 8:1-5.

Sirenko, B. I. 2000. Feeding of Polyplacophora and its role in evolution of the class. Pages 129-134 in: A. F. Alimov, B. I. Sirenko, and E. N. Egorova, editors, Marine Molluscs: problems of taxonomy, ecology and phylogeny. Zoological Institute of Russian Academy of Sciences, St Petersburg, Russia.

Smith, M. R. 2012. Mouthparts of the Burgess Shale fossils Odontogriphus and Wiwaxia: implications for the ancestral molluscan radula. Proceedings of the Royal Society B 279:42874295. http://dx.doi.org/10.1098/rspb.2012.1577

Squires, H. J., and J. H. Barragan. 1979. Lolliguncula panamensis (Cephalopoda: Loliginidae) from the Pacific Coast of Colombia. The Veliger 22:67-74.

Stephens, D. W., and J. R. Krebs. 1986. Foraging Theory. Princeton University Press, Princeton, USA.

Tang, I., and H. W. Khoo. 1974. The food and feeding habits of the cuttlefish Sepiella inermis (Férussac and d'Orbigny). The Veliger 16:405-410.

Taylor, J. D. 1996. Origin and evolutionary radiation of the Mollusca. Oxford University Press, Oxford, UK.

Teichert, C. 1988. Main features of cephalopod evolution Pages 11-79 in: M. R. Clarke, and E. R. Truman, editors, The Mollusca, 12, Paleontology and Neontology of Cephalopods. Academic Press Inc., New York, USA.

Tendal, O. S. 1985. Xenophyophores (Protozoa, Sarcodina) in the diet of Neopilina galatheae (Mollusca,
Monoplacophora). Galathea Report 16:95-98. http://dx.doi.org/ 10.1093/mollus/eyp013

Towsend, C. R., M. Begon, and J. Harper. 2010. Fundamentos em ecologia. $3^{\mathrm{a}}$ edição. Artmed, Porto Alegre, Brasil. Urgorri, V., García-Alvarez, O., and Á. Luque. 2005. Laevipilina cachuchensis, a new neopilinid (Mollusca: Tryblidia) from off North Spain. Journal of Molluscan Studies 71:59-66. http://dx.doi.org/10.1093/mollus/eyi008

Villanueva, R., C. Nozais, and S. V. Boletzky. 1996. Swimming behaviour and food searching in planktonic Octopus vulgaris Cuvier from hatching to settlement. Journal of Experimental Marine Biology and Ecology 208:169-184. http:// dx.doi.org/10.1016/S0022-0981(96)02670-6

Voight, J. R. 2008. Observations of deep-sea octopodid behavior from undersea vehicles. American Malacological Bulletin 24:43-50. http://dx.doi.org/10.4003/0740-2783-24.1.43

Ward, P., and M. K. Wicksten. 1980. Food sources and feeding behavior of Nautilus macromphalus. The Veliger 23:119-124.

Warén, A., and S. Hain, S. 1992. Laevipilina antarctica and Micropilina arntzi, two new monoplacophorans from the Antartic. The Veliger 35:165-176.

Wells, M. J. 1989. Oxigen uptake and the effect of feeding in Nautilus. The Veliger, 30:70-75.

Westermann, B., and K. Beurlein. 2005. Y-maze experiments on the chemotactic behaviour of the tetrabranchiate cephalopod Nautilus pompilius (Mollusca). Marine Biology 147:145-151. http://dx.doi.org/10.1007/s00227-005-1555-3

Westermann, B., and R. Schipp. 1998. Morphology and histology of the digestive tract of Nautilus pompilius and Nautilus macromphalus (Cephalopoda, Tetrabranchiata). Zoomorphology 117:237-245. http://dx.doi.org/10.1007/s004350050048

Wilson, N. G., D. Huang, M. C. Goldstein, H. Cha, G. Giribet, and G. W. Rouse. 2009. Field collection of Laevipilina hyalina McLean, 1979 from southern California, the most accessible living monoplacophoran. Journal of Molluscan Studies 75:195-197. http://dx.doi.org/10.1093/mollus/eyp013

Wodinsky, J. 1978. Feeding behaviour of broody female Octopus vulgaris. Animal Behaviour 26:803-813. http://dx.doi.org/ 10.1016/0003-3472(78)90145-8 